\title{
NOTES ON THE CAPE COD BROOD OF PERIODICAL CICADA DURING 1923.
}

\section{By Donald S. Lacroix.}

Massachusetts Agricultural Experiment Station.

The Cape Cod brood of Tibicen septendecim L. has been one watched with great interest since the early colonial days of Massachusetts, and it was during those days that it first came to the attention of the colonists who were then settling in and around Plymouth.

Early this year (1923) Dr. H. T. Fernald of the Massachusetts Agricultural College called my attention to the fact that the Periodical Cicada was due to appear on the Cape this season, and he asked me to observe the brood, to get some idea of its range and abundance.

The first record I obtained was on June 13th when Dr. H. J. Franklin of the Cranberry Experiment Station at East Wareham, gave me several specimens of $T$. septendecim which had been given to him the day before. The gentleman who brought them in said that he found them in abundance near Pocasset, Mass., in the town of Bourne.

On June 15th I went to that territory and struck into the woods for a distance of a half mile when I came into the infested area. This was one mile east of Monument Beach (a part of Bourne). It may be interesting to note at this point that part of this territory had been burned over by a tremendous forest fire on May 23rd-26th (inclusive), 1923, and that the brood appeared first in the burned area. On reaching this territory I met Mr. Lumbert who owns a considerable amount of land there. He told me that the Cicadas had been out for about two weeks (making the first appearance on or about June 1st). Examination of the burned area showed "chimneys" all over the ground, some of them partially charred, indicating that they had probably been constructed prior to the invasion of the forest fire. In many cases the chimneys were very numerous, one to a square foot of ground where they were thickest. 
The "active pupæ" were emerging until about June $22 \mathrm{~d}$, the height of the emergence apparently coming from about the 16th to the 19th. At this time, during the evenings, tremendous swarms of immature forms came out of the ground and ascended any upright object within range. Mr. Lumbert claimed to have seen several nymphs come out of a single chimney during this time. He also told me he had found active pupæ in the spring, about 18 inches below the surface of the ground. The adults were usually all on the wing by the morning following nymphal emergence.

On June 20th my attention was called to another part of the brood in Plymouth, between that place and Manomet on a ridge known locally as The Pine Hills. On the same date, I received reports of Cicadas infesting territory from Falmouth east to Osterville; and on Wing's Neck, which is a part of Bourne extending westward into the waters of Buzzards Bay. On June 21st two specimens were taken in East Wareham near the State Cranberry Bog.

The area of infestation of the Cape Cod brood for 1923 may be described as follows:

Town of Plymouth.-From the southern end of the village (Plymouth proper) southeast to Manomet and west from there to Great South Pond; a second area around the northern end of Great Herring Pond.

Town of Wareham.--Eastern corner.

Town of Bourne.-The whole town more or less, the heaviest infestation occurring on the south side of the Cape Cod canal from Bourne High School eastward to Sagamore and southward to Bourne-Falmouth town line, and westward to within one mile of the Coast line of Buzzards Bay except at Wings Neck, where the infestation came to the water's edge.

Town of Falmouth.-Whole town except from Falmouth village to Woods Hole where only a few specimens were taken after full emergence had taken place to the northward.

Town of Sandwich.-Whole town except a strip one to two miles wide along Cape Cod Bay.

Town of Mashpee.-Whole town.

Town of Barnstable.--Southern half of town. 
Town of Yarmouth.-Whole town except a strip about one to one and a half miles wide along Cape Cod Bay.

The heaviest infestations were in the Plymouth Pine Hills central and southern part of Bourne, northern, central and eastern Falmouth, Mashpee, southern Barnstable, central Sandwich and central Yarmouth.

Individual, lone specimens were taken at East Wareham, Ellisville (southeastern Plymouth), Woods Hole, Harwich, and Carver indicating, possibly, the former existence of parts of this brood in those sections. Fishermen from Woods Hole said that Cicadas could frequently be found floating in the ocean south of the Falmouth shore. I obtained no record of any on the Islands. (Nantucket or Marthas Vineyard).

Older inhabitants of the village of East Wareham tell me that they remember two broods previously when the insect was abundant in the village.

Mr. Lumbert of Monument Beach called my attention to a "big green beetle" which was preying on adult Cicadas and I asked him to collect some for me if he found more. This he did, and I found that it was the Calosoma beetle, C. sycophanta L. Later, in company with Prof. W. H. Sawyer, of the Department of Biology, Bates College, I took several Calosomas in the act of capturing Cicadas.

The order of emergence for this brood, as nearly as I can make out, is as follows: 1st week in June at Bourne; 2nd week in June at Falmouth, Mashpee, Sandwich, Yarmouth, Barnstable, and Plymouth (south of village); 3rd week in June at Plymouth (north of Great Herring Pond).

In driving through the infested territories south and east of the Cape Cod Canal, on July 11th, I found that by far the greatest damage done by this brood of $T$. septendecim L. occurs in the eastern part of the town of Falmouth, around the village of Waquoit. Here the insect has deposited its eggs in practically every suitable plant, including ferns, false indigo and goldenrod. Almost every oak from one to twenty feet high has dead and dying twigs hanging from it in abundance. In several cases I saw oaks twelve feet high and three or four inches through at the base with foliage entirely brown, and much of the youngest 
growth already drooping. A list of plants attacked is herewith submitted. I suspect many more could be added to the list by other observers, but the following have come to my attention: Aster spp. (Wild Asters), Baptisia tinctoria (False indigo), Linaria canadensis, Myrica asplenifolia (Sweet Fern), Prunus serotina (Black Cherry), (Prunus cuneata) (Plum), Pteris auilina (Common Brake), Pyrus Malus (Apple), Quercus illcifolia (Scrub Oak) and Quercus rubra (Red Oak), Robinia Pseudo-Acacia (Locust), Solidago spp. (Goldenrod), Vaccinium spp. (Blueberry and huckleberry), Viburnum cassinoides, Vitis sp. (Grape).

Quercus ilicifolia (scrub-oak) is the favorite host for oviposition in every case, but lack of room on the oaks, and lack of oaks have driven the females to laying in practically any woody plant available.

One of the interesting points in this season's occurrence of the Cicada, is the uneven emergence through the whole brood; often sections of the brood but a few miles distant from one another emerging at different times. Another interesting feature is the "patchy" occurrence throughout the area of infestation. Some places are heavily infested and others within the suspected area are practically free from the insect, although the same host plants and the same soil conditions exist in both cases. The digging of the Cape Cod Canal has disrupted part of the brood, as no Cicadas could be found within 100-500 feet of the canal banks.

About July 1st dead Cicadas could be picked up frequently in the infested area and by July 11th, dead and dying Cicadas could be found in abundance. By the middle of July very few living specimens could be found in Bourne, but the section of the brood around Great Herring Pond was still in full operation. 

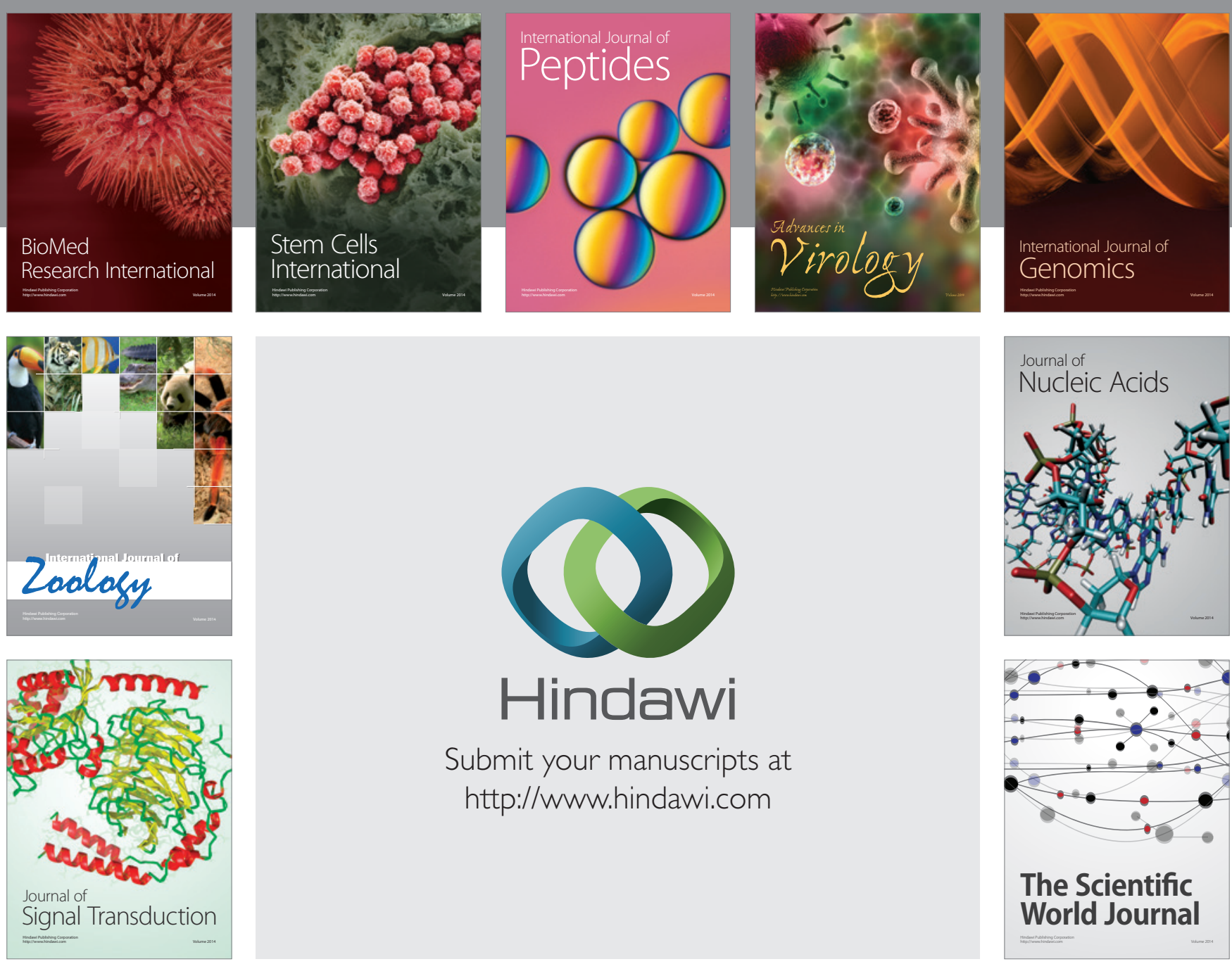

Submit your manuscripts at

http://www.hindawi.com
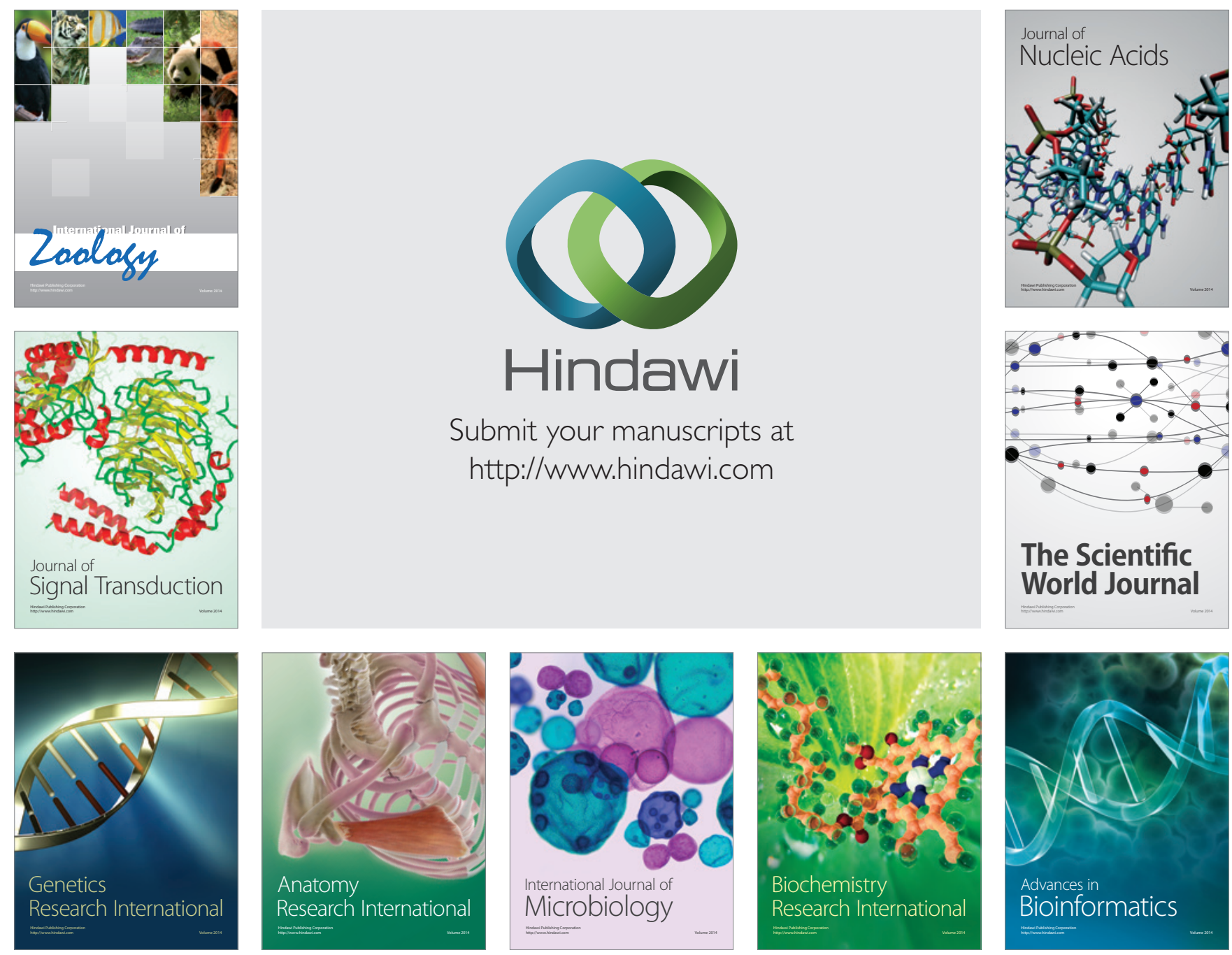

The Scientific World Journal
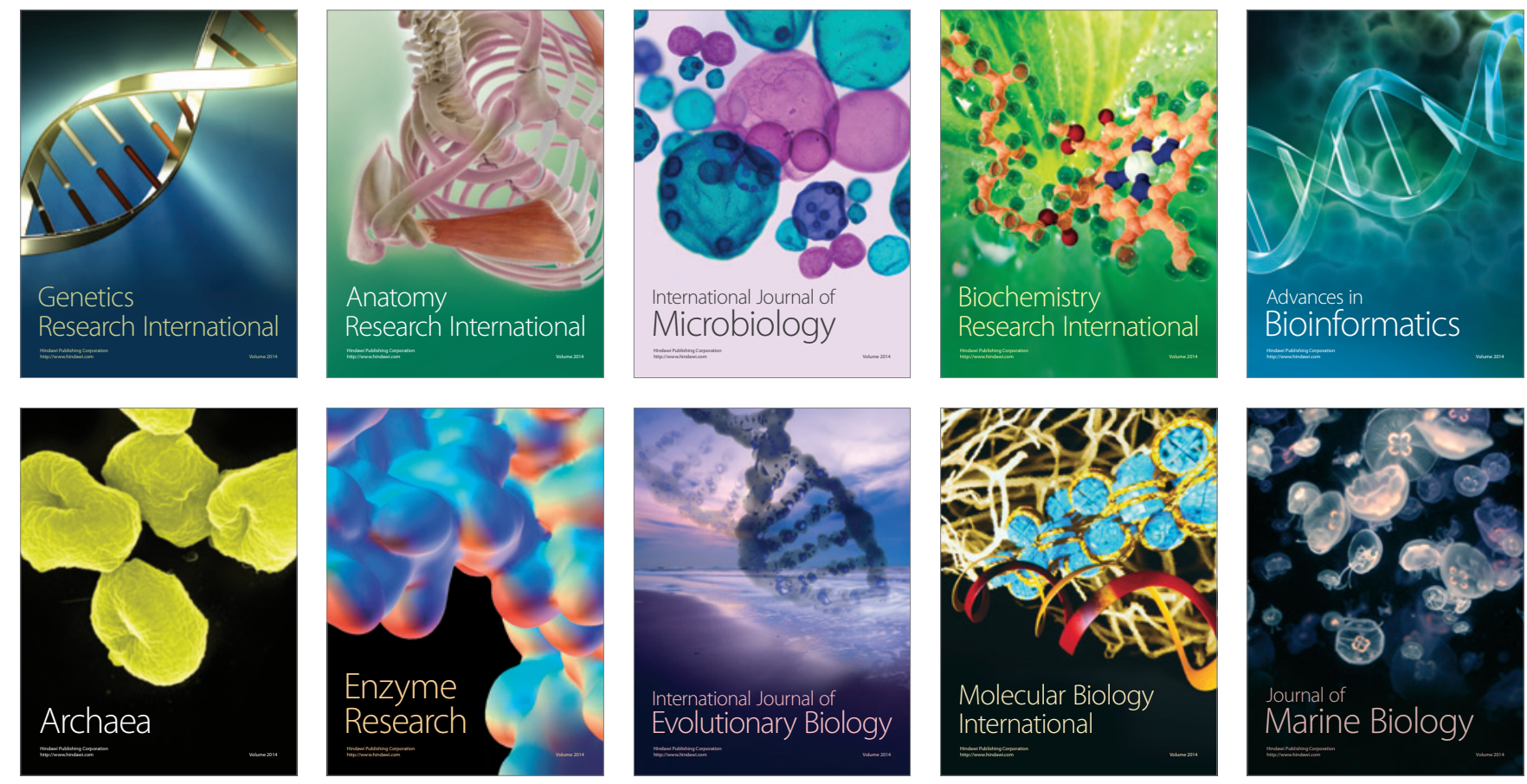